\title{
DETERMINING FACTORS RELATED TO THE TYPE OF CONTRACEPTIVES IN INDONESIA
}

\author{
Natya Ayu Candrika Ramania \\ Department of Biostatistics and Population, Faculty of Public Health, Universitas Airlangga, 60115 Surabaya, \\ East Java, Indonesia \\ Corresponding Author: Natya Ayu Candrika Ramania \\ E-mail: natyaayu17@gmail.com
}

\begin{abstract}
Family Planning Program is a government program designed as an effort to control population. The government initially recommends non-hormonal contraception, however in Indonesia, the use of non-hormonal contraception is less desirable by women of childbearing age. Most women of childbearing age in Indonesia prefer to use hormonal contraception. The study was conducted to determine the relationship between age, education, occupation, residential area, number of children alive, health insurance, husband's support by determining the type of contraception in women of childbearing age in Indonesia. The study utilized secondary data obtained from the 2017 IDHS by using a cross-sectional design. The research sample is subjects who put the last type of contraception in a private midwivery and subjects who use implanted contraception, injections, pills, condoms, and IUD. The sample size in this study was 6,030 subjects. According to the study, several factors were found that showed a relationship with the determination of the type of contraceptives in Indonesia. These factors include age, level of education, employment status, residential area, number of children alive, and health insurance. However, the husband's support factor shows that it has no relationship with determining the type of contraceptives for women of childbearing age in Indonesia.
\end{abstract}

Keywords: family planning program, hormonal contraception, non-hormonal contraception

\begin{abstract}
ABSTRAK
Program KB yakni program pemerintah yang dirancang sebagai upaya mengendalikan pertambahan warga negara. Pemerintah menganjurkan untuk menggunakan kontrasepsi non hormonal. Namun di Indonesia penggunaan kontrasepsi non hormonal kurang diminati oleh WUS di Indonesia. Sebagian besar WUS di Indonesia lebih memilih menggunakan kontrasepsi hormonal. Penelitian dilakukan untuk mengetahui hubungan antara usia, pendidikan, pekerjaan, tempat tinggal, jumlah anak yang masih hidup, asuransi kesehatan, dukungan suami dengan penentuan jenis kontrasepsi pada WUS di Indonesia. Penelitian memanfaatkan data sekunder yang didapatkan dari SDKI 2017 dengan memanfaatkan desain cross sectional. Sampel penelitian yakni subjek yang memasang jenis kontrasepsi terakhir di bidan pribadi dan subjek yang menggunakan kontrasepsi implan, suntik, pil, kondom, dan IUD. Besar sampel dalam penelitian ini adalah 6.030 subjek. Menurut penelitian diperoleh beberapa faktor yang memperlihatkan hubungan dengan penentuan jenis kontrasepsi WUS di Indonesia. Faktor tersebut antara lain usia, jenjang pendidikan, status pekerjaan, wilayah tempat tinggal, jumlah anak hidup, dan asuransi kesehatan. Namun faktor dukungan suami memperlihatkan bahwa tidak memiliki hubungan dengan penentuan jenis kontrasepsi WUS di Indonesia.
\end{abstract}

Kata kunci: program Keluarga Berencana, kontrasepsi hormonal, kontrasepsi non hormonal

\section{INTRODUCTION}

A large population increase will cause problems for a country. The country of Indonesia is a developing country where there are too many citizens in the world. The population of Indonesian citizens based on Central Bureau of Statistics in 2018 were 265.0 million (Central Bureau of Statistics,
2019). This number has increased from the 2010 census. The increasing population in a country can cause problems in that country. This happens because it will hinder and complicate the work of the government in terms of improving and leveling the welfare of the population. The greater the increase in population growth, the efforts that need to be 
done in terms of protecting the welfare of the population are also greater.

The government's effort to curb population growth in Indonesia is to control birth rates. National Board of Population and Family Planning was created by the government to control population growth in Indonesia. Government programs through the National Board of Population and Family Planning to control population increase through the Family Planning program. The targets of this program are pro natalis, determining the type of contraception, limiting citizens, qualified citizens, male family planning participants, changing management of family planning, improving welfare, and the Population Family Planning and Family Development (PFPFD) program (Putri et al., 2019a).

Contraception services are part of the family planning program. Contraception is a tool that functions to delay and prevent pregnancy. This pessary can be permanent and not permanent or temporary. The installation of some contraceptives requires services help from a doctor or midwife who has been trained.

Contraception can be divided into modern contraception and conventional contraception (Indonesian Ministry of Health, 2013). Sterilization or medical operative for women (tubectomy) and medical operative for men (vasectomy), IUD, injection, implants, pills, condoms, and Lactation Amenorrhoea Method (LAM) belong to modern contraception. While abstinence or calendar and interrupted intercourse classified as conventional contraception. When deciding which type of contraceptives to use, it should be adjusted to the circumstances and needs of each family planning participant.

In 2018 the number of active family planning participants in Indonesia who used modern contraception was 23,953,958 participants, while those who used conventional contraception were 304,574 participants (Indonesian Ministry of Health, 2018). This situation indicates that modern contraception is more preferrable compared to conventional contraception by most of the Indonesian population. The most widely used modern contraception is $15,261,014(63.71 \%)$ injections, 4,130,495 (17.24\%) pill types, $1,759,862$ (7.35\%) IUD types, 1,724,796 (7.20\%) implant types, 660,259 (2.76\%) medical operative for women (tubectomy) types, 298,218 (1.24\%) condom types, and the least favorable were medical operative for men (vasectomy) types $119,314 \quad(0.50 \%)$ (Indonesian Ministry of Health, 2018).

In Indonesia, the determination of the contraception types is largely directed to hormonal contraceptives such as injections, pills, and implants. While the government itself has advocated using non-hormonal contraceptives such as IUD, Lactation Amenorrhoea Method (LAM), a medical operative for women (tubectomy), medical operative for men (vasectomy), and condoms. Hormonal contraception is a tool to enforce pregnancy by utilizing ingredients based on estrogen and progesterone preparations (Sriwahyuni and Wahyuni, 2012). One of the non-hormonal contraception is IUD. The use of an IUD has several advantages such as its higher effectiveness and can be used for a long time. More hormonal contraception is used because it is easy to use and find. Whereas non-hormonal contraception was chosen on the advice of health workers such as doctors and midwives (Liwang et al., 2018).

According to the incident, the researcher is interested in knowing the factors associated with determining the contraception types for women of childbearing age in Indonesia.

\section{METHODS}

This research is quantitative by utilizing secondary data obtained from the 2017 IDHS, and using a cross-sectional approach. Crosssectional observational research is most often done because the dependent and independent variables are tested in the same event.

The population of the 2017 IDHS data is childbearing age women in Indonesia. All sample sizes according to IDHS in 2017 were 49,627 subjects. Based on the criteria set by researchers, a sample of 6,030 subjects was obtained. Researchers' criteria include subjects who had contraceptives installed in a private midwivery and subjects who used implanted contraceptives, injections, pills, IUD, and condoms. Implanted contraceptives, injections, and pills are categorized as hormonal contraception, while condom and IUD as nonhormonal contraception. A total of 6,030 subjects consisted of 5,652 hormonal contraceptive participants and 378 nonhormonal contraceptive participants. 
The dependent variable of this study is the type of contraception that is hormonal and non-hormonal. While the independent variables are age, health insurance, education, residential area, work, the number of children alive, and husband support. The study was conducted to determine the relationship of age, education, occupation, residential area, the number of children alive, health insurance, husband's support by determining the type of contraception in women of childbearing age in Indonesia. The analysis is done descriptively and the analysis uses the chi-square test. The data obtained is then continued by processing and analyzing using a computer with the help of the SPSS application.

\section{RESULT}

\section{Univariate Analysis}

The characteristics of the subjects of this study are age, education, occupation, and residential area, number of children alive, health insurance, husband's support, and types of contraception.

According to table 1 that 6,030 subjects were found to use the majority of contraceptives in the age range of 20-34 years as many as 3,098 people $(51.4 \%)$. Whereas at the age of $<20$ years old is the age of the least use of contraception as many as 127 people $(2.1 \%)$. Based on the level of education, from 6,030 most subjects using contraceptives were those with secondary education of 3,465 people $(57.5 \%)$. While the lowest is in subjects who are not educated or no education as many as 67 people $(1.1 \%)$.

Based on employment status, of 6,030 working subjects were 3,208 people (53.2\%). While 2,822 people (46.8\%) were not using contraception. Based on the region of residence, of 6,030 subjects residing in urban areas as many as 3,305 people $(54.8 \%)$ while in rural areas as many as 2,725 people (45.2\%) had used contraception. Based on the number of live children, of 6,030 subjects using contraception and having live children $\leq 2$ were 4,201 people $(69.7 \%)$ while those who had live children $>2$ there were 1,829 people (30.3\%).
Based on the use of health insurance, of 6,030 subjects there were 5,823 people $(96.6 \%)$ not using health insurance and as many as 207 people (3.4\%) using health insurance. Based on husband support, of 6,030 subjects there were 117 people $(1.9 \%)$ of their husbands not agreeing to use contraception while 5,913 people (98.1\%) had supported and agreeing. Based on the type of contraception used, of 6,030 subjects there were 5,652 people (93.7\%) using the hormonal type, while those using the non-hormonal type there were 378 people $(6.3 \%)$.

Table 1. Distribution of Subject Characteristics Based on Age, Education Level, Occupation, Residential Area, Number of Children Alive, Health Insurance, Husband's Support, and Type of Contraception

\begin{tabular}{|c|c|c|}
\hline Subject Characteristics & $\mathbf{f}$ & $\%$ \\
\hline \multicolumn{3}{|l|}{ Age in years } \\
\hline$<20$ & 127 & 2.1 \\
\hline $20-34$ & 3,098 & 51.4 \\
\hline$>34$ & 2,805 & 46.5 \\
\hline \multicolumn{3}{|l|}{ Education level } \\
\hline No Education & 67 & 1.1 \\
\hline Primary & 1,986 & 32.9 \\
\hline Secondary & 3,465 & 57.5 \\
\hline Higher & 512 & 8.5 \\
\hline \multicolumn{3}{|l|}{ Occupation } \\
\hline No & 2,822 & 46.8 \\
\hline Yes & 3,208 & 53.2 \\
\hline \multicolumn{3}{|l|}{ Residence } \\
\hline Urban & 3,305 & 54.8 \\
\hline Rural & 2,725 & 45.2 \\
\hline \multicolumn{3}{|c|}{ Number of children alive } \\
\hline$\leq 2$ & 4.201 & 69.7 \\
\hline$>2$ & 1,829 & 30.3 \\
\hline \multicolumn{3}{|l|}{ Health Insurance } \\
\hline No & 5,823 & 96.6 \\
\hline Yes & 207 & 3.4 \\
\hline \multicolumn{3}{|l|}{ Husband's support } \\
\hline Disagree & 117 & 1.9 \\
\hline Agree & 5,913 & 98.1 \\
\hline \multicolumn{3}{|l|}{ Contraception Types } \\
\hline Hormonal & 5,652 & 93.7 \\
\hline Non-hormonal & 378 & 6.3 \\
\hline Total & 6,030 & 100.0 \\
\hline
\end{tabular}




\section{Bivariate Analysis}

Table 2. Cross Tabulation Factors Related to Determination of Contraception Type

\begin{tabular}{|c|c|c|c|c|c|}
\hline \multirow{3}{*}{ Research variable } & \multicolumn{2}{|c|}{ Contraception Type } & \multirow[b]{2}{*}{ Total } & \multirow[b]{2}{*}{ p-value } & \multirow{2}{*}{$\begin{array}{c}\text { Chi- } \\
\text { Square }\end{array}$} \\
\hline & Hormonal & $\begin{array}{c}\text { Non- } \\
\text { Hormonal }\end{array}$ & & & \\
\hline & $\mathbf{N}$ & $\mathbf{N}$ & $\mathbf{N}$ & & \\
\hline \multicolumn{6}{|l|}{ Age (in years) } \\
\hline$<20$ & 126 & 1 & 127 & \multirow{4}{*}{0.000} & \multirow{4}{*}{46.682} \\
\hline $20-34$ & 2,959 & 139 & 3,098 & & \\
\hline$>34$ & 2,567 & 238 & 2,805 & & \\
\hline Total & 5,652 & 378 & 6,030 & & \\
\hline \multicolumn{6}{|l|}{ Education Level } \\
\hline No Education & 63 & 4 & 67 & \multirow{5}{*}{0.000} & \multirow{5}{*}{169.080} \\
\hline Primary & 1,931 & 55 & 1,986 & & \\
\hline Secondary & 3,240 & 225 & 3,465 & & \\
\hline Higher & 418 & 94 & 512 & & \\
\hline Total & 5,652 & 378 & 6,030 & & \\
\hline \multicolumn{6}{|l|}{ Occupation } \\
\hline No & 2,692 & 130 & 2,822 & \multirow{3}{*}{0.000} & \multirow{3}{*}{24.408} \\
\hline Yes & 2,960 & 248 & 3,208 & & \\
\hline Total & 5,652 & 378 & 6,030 & & \\
\hline \multicolumn{6}{|l|}{ Residential Area } \\
\hline Urban & 3,014 & 291 & 3,305 & \multirow{3}{*}{0.000} & \multirow{3}{*}{79.109} \\
\hline Rural & 2,638 & 87 & 2,725 & & \\
\hline Total & 5,652 & 378 & 6,030 & & \\
\hline \multicolumn{6}{|l|}{ Number of Children Alive } \\
\hline$\leq 2$ & 3,968 & 233 & 4,201 & \multirow{3}{*}{0.001} & \multirow{3}{*}{11,898} \\
\hline$>2$ & 1,684 & 145 & 1,829 & & \\
\hline Total & 5,652 & 378 & 6,030 & & \\
\hline \multicolumn{6}{|l|}{ Health Insurance } \\
\hline No & 5,474 & 349 & 5,823 & \multirow{3}{*}{0.000} & \multirow{3}{*}{20.518} \\
\hline Yes & 178 & 29 & 207 & & \\
\hline Total & 5,652 & 378 & 6,030 & & \\
\hline \multicolumn{6}{|l|}{ Husband's Support } \\
\hline Disagree & 113 & 4 & 117 & \multirow{3}{*}{0.275} & \multirow{3}{*}{1.192} \\
\hline Agree & 5,539 & 374 & 5,913 & & \\
\hline Total & 5,652 & 378 & 6,030 & & \\
\hline
\end{tabular}

According to table 2, it can be seen that from 6,030 subjects aged $<20$ who chose the hormonal type as many as 126 subjects and those who chose the non-hormonal type there was only 1 subject. In the age range of 20-34, 2,959 subjects chose the hormonal type and 139 subjects chose the non-hormonal type. In the subjects aged > 34, as many as 2,567 subjects chose the hormonal type, and those who chose the non-hormonal type were 238 subjects. Obtaining a chi-square test showing $\mathrm{p}$ of 0.000 shows that $p<\alpha(0.05)$. These results explain that there is a relationship between maternal age and the determination of the type of contraceptives in women of childbearing age in Indonesia.

Based on the level of education, from 6,030 subjects using contraception most at the secondary level, 3,240 subjects chose the hormonal type and 225 subjects chose the nonhormonal type. In subjects who were not educated or no education as many as 63 subjects chose the hormonal type and 4 others chose the non-hormonal type. On subjects at the primary level as many as 1,931 subjects chose the hormonal type and 55 others chose 
the non-hormonal type. Subjects with a higher education level of 418 subjects chose the hormonal type and as many as 94 others chose the non-hormonal type. Obtaining a chi-square test showing $\mathrm{p}$ of 0.000 shows that $\mathrm{p}<\alpha$ $(0.05)$. These results explain the relationship between education levels and the determination of the type of contraceptives in women of childbearing age in Indonesia.

Based on employment status, of 6,030 subjects, 2,960 subjects are currently working on choosing hormonal type while those who choose non-hormonal types are 248. In subjects who are currently not working 2,692 subjects are choosing the hormonal type and as many as 130 subjects choosing non-hormonal type. Obtaining a chi-square test showing $\mathrm{p}$ of 0.000 shows that $\mathrm{p}<\alpha(0.05)$. These results explain that there is a relationship between current employment status and the determination of the type of contraception in women of childbearing age in Indonesia.

Based on the area of residence, of 6,030 subjects residing in urban areas, 3,014 subjects were choosing the hormonal type and 291 subjects choosing the non-hormonal type. While residing in rural areas 2,638 subjects were choosing the hormonal type and 87 others chose the non-hormonal type. The acquisition of chi-square statistical tests showed a p-value of 0.000 which indicates that $\mathrm{p}<\alpha(0.05)$. These results explain that there is a relationship between the residential area and the determination of the type of contraceptives in women of childbearing age in Indonesia.

Based on the number of children alive, of 6,030 subjects who had children alive are $\leq 2$, 3,968 subjects chose the hormonal type and 233 subjects chose the non-hormonal type. While subjects with living children $>2$ as many as 1,684 chose the hormonal type and 145 subjects chose the non-hormonal type. The acquisition of the chi-square test showed a pvalue of 0.001 which showed that $p<\alpha(0.05)$. These results explain the relationship between many children who live with the determination of the type of contraception in women of childbearing age in Indonesia.

Based on health insurance, from 6,030 subjects who did not receive national health insurance, 5,474 subjects were choosing the hormonal type and 349 subjects chose the nonhormonal type. While those who had national health insurance as many as 178 chose the hormonal type and 29 subjects chose the non- hormonal type. The acquisition of chi-square statistical tests showed a p-value of 0.000 which indicates that $\mathrm{p}<\alpha(0.05)$. These results explain there is a relationship between health insurance with the determination of the type of contraceptives in women of childbearing age in Indonesia.

Based on the husband's support, of 6,030 subjects who received approval from the husband as many as 5,539 subjects chose the hormonal type and 374 subjects chose the nonhormonal type. While those who did not get approval from the husband were 113 subjects who chose the hormonal type and 4 others chose the non-hormonal type. An obtained chisquare statistical test obtained $\mathrm{p}$ of 0.275 which shows that $\mathrm{p}>\alpha(0.05)$. These results explain there is no relationship between husband's supports with the determination of the type of contraceptives in women of childbearing age in Indonesia.

\section{DISCUSSION}

\section{Mother's age}

A person's way of thinking will develop in line with age so that the knowledge gained also tend to be better. Age of $20-35$ is considered as childbearing age for women because of the reproductive organs in a situation that is optimal for reproduction. At the age of 20-35, women prefer hormonal contraception due to the limitation and spacing of pregnancy, while non-hormonal contraception has little interest because of the fear of using these devices not having enough experience and the husband does not approve (Priyanti and Syalfina, 2017). The use of this type of contraceptives needs to be considered to suit the conditions and needs of the individual.

At age $<20$, it is recommended to use contraception in the form of pills, IUD, and condoms while at the age of 20-30 years it is recommended to use contraception in the order of IUD, pills, injections, implants, condoms, and steady contraceptive (Rizali, Ikhsan, and Salmah, 2013). At the age of $>35$, it is expected to choose contraception with high effectiveness (Putri et al., 2019b). Higheffectiveness contraceptives such as medical operatives for women (tubectomy). However, its use must be well-considered and mature 
because medical operative for women (tubectomy) is a strong contraceptive.

The $p$-value in this study shows the relationship between maternal age and the determination of the type of contraceptives. These results agree with previous research from Aryati, Sukamdi, and Widyastuti (2019). In contrary to Syukaisih (2015) which says the opposite does not indicate a relationship between maternal age and the determination of the type of contraceptives.

\section{Educational Level}

Based on factors in the level of education, the subject shows women of childbearing age in Indonesia prefer hormonal contraception over non-hormonal contraception and most are in secondary education. The level of education is one of the variables when determining the type of contraceptives in this study. High and low levels of one's education can affect someone when thinking and making decisions. Decisions in determining contraception must be made correctly and according to the condition of the body.

If an error occurs in determining can affect the condition of the body. For example, mothers who give birth normally are advised to use an IUD because the breastfeeding process is running properly and the mother's womb is suitable for using an IUD (Liwang et al., 2018). Higher education will make people think rationally. This will make it easy for someone to receive information, input, and ideas. And in the end in making decisions taken can be decided appropriately and in proportion to their needs.

The p-value in this study shows the relationship between education levels and the determination of the type of contraceptives. These results concur with previous research from Rizali, Ikhsan, and Salmah (2013). However, contrary to Saragih, Suharto, and Nugraheni (2018), it does not indicate a relationship between education levels and the determination of the type of contraceptives.

\section{Occupation}

Based on the occupation, most women of childbearing age work. The number of women of childbearing age whose work is greater and chooses hormonal contraception. In this study, injectable contraception was most widely used on women of childbearing age that worked.
The use of injectable contraception is safe and practical and has a success value of $99 \%, 3$ monthly injection contraception will not affect breast milk and can be used on breastfeeding mothers (Bakri, Kundre and Bidjuni, 2019). In the opinion of researchers, the use of injection contraception does not inhibit activities at work because there are no contraceptives installed in the body.

Women who have jobs with excessive activity can cause complications in the use of an IUD (Ningrum, Easter, and Sugihati, 2018). Contraceptive complications are disorders of health ranging from mild to severe levels in contraceptive users that occur due to using contraception (Indonesian Ministry of Health, 2014). As a woman who has a job, managing pregnancy is important to maintain her work career (Triyanto and Indriani, 2018). As well as working mothers will interact with many people so that it will likely get a lot of new insights.

The p-value in this study shows the relationship between work status and the determination of the type of contraception. These results concur with previous research from Yulidasari, Lahdimawan, and Rosadi (2015). But contrary to Aryati, Sukamdi and Widyastuti (2019) which says the opposite does not indicate a relationship between work status and the determination of the type of contraception.

\section{Residential Area}

Based on the residential area of women of childbearing age in Indonesia, most live in urban areas rather than rural areas. Urban areas are areas that allow access to get contraceptives easily found. Whereas contraceptives are difficult to obtain in rural areas to obtain because it is too far to reach health care facilities. At women of childbearing age Indonesia the majority use of non-hormonal contraception in urban areas. This is likely because the facility to obtain contraceptives is easier to find. Subjects who have a place to live in urban areas are more likely to use an IUD (Triyanto and Indriani, 2018).

The p-value in this study shows the relationship between residential area and the determination of the type of contraceptives. These results are in accordance with previous research from Triyanto and Indriani (2018). 


\section{Number of Children Alive}

The number of children alive concerning programs that aim to regulate many children in the family and welfare level of a family. Most women of childbearing age have $\leq 2$ children and choose the hormonal type. Selection of hormonal contraception in mothers who have $\leq$ 2 children, is considered inappropriate because if the mother forgets to reuse her contraception routinely the possibility of pregnancy will occur again and cause the birth control to fail. A family that has children $\leq 2$ is expected to not have children again and enough to have 2 children. And determine exactly which contraception will be used with due regard to the higher success rate to avoid pregnancy.

The result of the p-value in this study is 0.001 which shows the relationship between the number of children with the determination of the type of contraceptives. This is in line with previous research from Weni, Yuwono, and Idris (2019). Nonetheless, Saragih, Suharto, and Nugraheni (2018) states the opposite, it does not indicate the relationship between number of children alive and the determination of the type of contraceptives.

\section{Health Insurance}

Relationships with health service facilities can be better if someone is covered by health insurance (Weni, Yuwono, and Idris, 2019). The utilization of health insurance for family planning services is still considered very little. Women who do not have health insurance for family planning services have a preference for injection contraception over long-term contraceptives (Winner et al., 2012). This opinion is suitable in this study because women of childbearing age in Indonesia who do not use health insurance mostly choose injection contraceptives.

Most women of childbearing age in Indonesia do not use health insurance for family planning services. This is likely due to the absence of a health insurance program that covers the cost of contraception. However, family planning program services have now been borne by the Social Insurance Adminisration Organization. These costs include counseling, condom administration, birth control pill services, injections (specifically for injections every 3 months), IUD, implants, a medical operative for women (tubectomy), a medical operative for men (vasectomy), and countermeasures for side effects.

The p-value in this study indicates the relationship of health insurance with the determination of the type of contraception. These results concur with previous research from Weni, Yuwono, and Idris (2019) and contrary to Saragih, Suharto, and Nugraheni (2018) which said the opposite, Community Health Insurance( $\mathrm{CHI}$ ) had no relationship with the determination of non-IUD contraception.

\section{Husband's Support}

Based on this study, husbands who provide support and choose hormonal are more than those who provide support and choose non-hormonal. The husband's support in using contraception is very much needed by a wife. Wives who get the husbands' support will cause the use of contraception to run smoothly and the wives follow the family planning program routinely which will indirectly support government policies in reducing birth rates.

The husband's support in paying for contraception services is also needed. But there are still husbands who think that the husband's support is unnecessary and give all the decisions to the wife. So that the husband feels no need to participate in discussions about contraception.

The p-value in this study shows that there is no relationship between the husband's support and the determination of the type of contraceptives. These results confirm previous research from Setiasih, Widjanarko, and Istiarti, 2016. In contrary to Bakri, Kundre, and Bidjuni (2019) which says that there is a relationship of husbands' support with the determination of the type of contraceptives.

\section{CONCLUSIONS AND SUGGESTIONS}

\section{Conclusion}

The conclusion based on the results of the analysis that the researchers have done is obtained several factors indicating a relationship with the determination of the type of contraceptives in women of childbearing in Indonesia. These factors include age, level of education, occupation, residential area, number of children alive, and health insurance. However, the husband's support factor shows 
no relationship with the determination of the type of contraceptives.

Some variables related to the determination of the type of contraception because of the educational factor, the high level of education of a person will affect the way in rational decision making related to the determination of the type of contraception. On the occupation factor, work will make individuals interact with many people so that it is likely to add a lot of new insights about contraception. In terms of the residential area, living in urban areas allows people to find contraceptives relatively easy. On the factor of the number of children alive, if a family has enough children, it is expected not to add more children by using the appropriate contraceptives. As well as the health insurance factor, having health insurance can make it easier for people to obtain family planning services.

\section{Suggestion}

The government is expected to provide further information and education to women of childbearing age and their husbands on the issue of contraception equally. And couples of childbearing age are expected to actively attend family planning counseling activities to get the true and right information from family planning staff.

\section{REFERENCES}

Aryati, S., Sukamdi, S., and Widyastuti, D., 2019. Faktor-Faktor yang Mempengaruhi Pemilihan Metode Kontrasepsi (Kasus di Kecamatan Seberang Ulu I Kota Palembang). Majalah Geografi Indonesia, 33(1), pp.79-85.

Bakri, Z., Kundre, R., and Bidjuni, H., 2019. Faktor-Faktor yang Berhubungan dengan Pemilihan Metode Kontrasepsi pada Wanita Usia Subur di Wilayah Kerja Puskesmas Ranotana Weru. Jurnal Keperawatan, 7(1), pp.1-10.

Central Bureau of Statistics, 2019. Statistik Indonesia 2019 Statistical Yearbook of Indonesia 2019. Jakarta: Badan Pusat Statistik.

Indonesian Ministry of Health, 2013. Buletin Jendela Data dan Informasi Kesehatan Situasi Keluarga Berencana di Indonesia. Jakarta: Indonesian Ministry of Health.
Indonesian Ministry of Health, 2014. Pedoman Manajemen Pelayanan Keluarga Berencana. Jakarta: Indonesian Ministry of Health.

Indonesian Ministry of Health, 2018. Data dan Informasi Profil Kesehatan Indonesia 2018. Jakarta: Indonesian Ministry of Health.

Liwang, F., Bhargah, A., Kusuma, I.B.H., Prathiwindya, G.G., Indaya, I.G., Putra, S., and Ani, L.S., 2018. Gambaran penggunaan kontrasepsi hormonal dan non hormonal di wilayah kerja UPT Puskesmas Tampak Siring 1. Intisari Sains Medis, 9(3), pp.41-46.

Ningrum, D.A.., Easter, D.Y., and Sugihati, 2018. Faktor-Faktor yang Berhubungan dengan Pemilihan Metode Kontrasepsi Jangka Panjang (MKJP) pada Pasangan Usia Subur di Wilayah Kerja Puskesmas Batang Hari Kabupaten Lampung Timur. Jurnal Dunia Kesmas, 7(4), pp.196-203.

Priyanti, S., and Syalfina, A.D., 2017. Alat Kontrasepsi dan Aktivitas Seksual Sebagai Faktor yang Berpengaruh Terhadap Kejadian Keputihan. Jurnal Berkala Epidemiologi, 5(3), pp.371-382.

Putri, P.K.., Hubeis, A.V, Sarwoprasodjo, S., and Ginting, B., 2019a. Kelembagaan dan Capaian Program Keluarga Berencana (KB): Dari Era Sentralisasi ke Desentralisasi. Jurnal Kependudukan Indonesia, 14(1), pp.1-12.

Putri, R.P., Dewi, R., Sari, P., and Ayu, P.R., 2019b. Perbandingan Faktor-Faktor yang Mempengaruhi Penggunaan Kontrasepsi Intra Uterine Devices (IUD) dan Kontrasepsi Implant pada Wanita Usia Subur di Kecamatan Sukarame Kota Bandarlampung. Majority, 8(2), pp.120124.

Rizali, M.I., Ikhsan, M., and Salmah, U., 2013. Faktor yang Berhubungan Pemilihan Metode Kontrasepsi Suntik di Kelurahan Mattoangin Kecamatan Mariso Kota Makassar. Media Kesehatan Masyarakat Indonesia, pp.176-183.

Saragih, I.M., Suharto, and Nugraheni, A., 2018. Faktor-Faktor yang Berhubungan dengan Pemilihan Penggunaan Metode Kontrasepsi Non-IUD pada Akseptor KB Wanita Usia Subur di Kelurahan Bandarharjo Semarang Utara. Jurnal Kedokteran Diponegoro, 7(2), pp.12361250. 
Setiasih, S., Widjanarko, B., and Istiarti, T., 2016. Analisis Faktor-faktor yang Mempengaruhi Pemilihan Metode Kontrasepsi Jangka Panjang (MKIP) pada Wanita Pasangan Usia Subur (PUS) di Kabupaten Kendal Tahun 2013. Jurnal Promosi Kesehatan Indonesia, 11(2), pp.32-46.

Sriwahyuni, E., and Wahyuni, C., 2012. Hubungan antara Jenis dan Lama Pemakaian Alat Kontrasepsi Hormonal dengan Peningkatan Berat Badan Akseptor. The Indonesian Journal of Public Health, 8(3), pp.112-116.

Syukaisih, 2015. Faktor-Faktor yang Berhubungan dengan Pemilihan Kontrasepsi di Puskesmas Rambah Samo Kabupaten Rokan Hulu. Jurnal Kesehatan Komunitas, 3(1), pp.34-40.

Triyanto, L., and Indriani, D., 2018. Faktor yang Mempengaruhi Penggunaan Jenis
Metode Kontrasepsi Jangka Panjang (MKJP) pada Wanita Menikah Usia Subur di Provinsi Jawa Timur. 11(2), pp.32-46.

Weni, L., Yuwono, M., and Idris, H., 2019. Determinan Pemilihan Metode Kontrasepsi Jangka Panjang Pada Akseptor KB Aktif di Puskesmas Pedamaran. Scientific Periodical of Public Health and Coastal Health, 1(1), pp.9-16. Winner, B., Peipert, J.F., Zhao, Q., Buckel, C., Madden, T., Allsworth, J.E., and Secura, G.M., 2012. Effectiveness of Long-Acting Reversible Contraception. The New England Journal of Medicine, 366(21), pp.1998-2007.

Yulidasari, F., Lahdimawan, A., and Rosadi, D., 2015. Hubungan Pengetahuan Ibu dan Pekerjaan Ibu dengan Pemilihan Kontrasepsi Suntik. Jurnal Berkala Kesehatan, 1(1), pp.33-36. 